\title{
Analysis of Ethnolinguistic Knowledge of Elementary School Teachers in Indonesia
}

\author{
Syahrial* Ahmad Hariandi Nur Amalina Dwi Agus Kurniawan \\ Faculty of Teaching and Education, Jambi University, Indonesia
}

\begin{abstract}
Ethnolinguistics in the learning perspective is the knowledge that teachers have about regional languages that are related or included in learning. This study aims to determine the ethnolinguistic knowledge of classroom teachers in Indonesia Elementary School, to know the ways and obstacles experienced by teachers in implementing ethnolinguistics in-class learning at Indonesia primary school. This study uses the mix methods approach with the sequential explanatory design. The sample in this study were 18 teachers. The sampling technique used purposive sampling. The quantitative data collection technique used was in the form of a questionnaire. Qualitative data collection techniques used are interviews and document analysis. The questionnaire data shows that elementary school teachers in Indonesia have ethnolinguistic knowledge in the less good category with an average of 30.72. Interview data obtained results about the ways teachers use ethnolinguistics in the classroom in terms of 4 aspects and data on the constraints of teachers in implementing ethnolinguistics can be viewed from five aspects.
\end{abstract}

Keywords: ethnolinguistic, regional language, implementation, teachers, elementary school.

DOI: $10.7176 / \mathrm{JEP} / 10-2-03$

\section{Introduction}

The curriculum is part of the component of the education system as well as a guideline in the implementation of educational activities. The curriculum is developed based on the principles of curriculum development. One of the principles in curriculum development is that the curriculum is developed according to the distinctive cultural content of each region. Beuchamp (2016) states that "Optimally, a curriculum should contain four parts: 1) a statement of intention for use of the document as a guiding force for planning instructional strategies, 2) statements outlining the goals for the school(s) for which the curriculum was designed, 3) a body of culture content that has the potential for the realization of the goals, and 4) a statement of an evaluation scheme for determining the worth and the effectiveness of the curriculum and the curriculum system".

The importance of cultural content is in the curriculum because each region has different characteristics and needs. The goal is so that students have a national character personality that comes from noble values contained in the wealth of national culture. Adilah (2013) argues that "In general, local content aims to provide sufficient knowledge, skills, and attitudes to students. So that they have an extensive knowledge in accordance with the local values or the rules prevailing in the region and support the preservation of regional development and national development". Knowledge of local values that apply in the region can build national cultural values. This is consistent with the statement, Anggraini and Kusniarti (2015) stating that "local wisdom serves with its function as to shape human beings to be wiser in undergoing their lives. In Indonesia, local wisdom is not necessarily applicable within local context or ethnic, but cross-cultur al or cross- ethnical natures as well, in hope of establishing national cultural value".

Cultural values, especially local wisdom, viewed from language have an important role in life because language is used as a medium of communication. This effort can be carried out through the education process. Integration of local wisdom values in the context of language into learning is referred to as ethnolinguistic. Riley (2007) states that "the main areas of etnholinguistics include the relationship between language and culture, communicative practices, and cognitive models of language and thought". Through ethnolinguistics that is integrated into learning, it can make students feel proud of having culture so that teachers can explore students' interest in culture and develop character values. "Currently character education is best understood as the deliberate attempt to promote the development of virtue, moral values, and moralagency in youth, especially in schools (Beland, 2003 in Berkowitz and Hoppe)".

Based on the preliminary study, the implementation of learning using ethnolinguistics in the low class and high class in the Public Elementary School of Indonesia has been implemented but the implementation has not been optimally implemented. The teacher has not explored ethnolinguistics into learning. Integration of ethnolinguistics, in particular, the insertion of regional languages into learning has not been optimally implemented. The lack of teachers in exploring ethnolinguistics into learning is caused by the weakness of knowing the abilities of teachers in the field of ethnology. This study aims to determine the ethnolinguistic knowledge of classroom teachers Elementary School in Indonesia, to know the ways and obstacles experienced by teachers in implementing ethnolinguistics in low-class and high-class learning in Indonesia Primary School. The formulation of the problem in this study are: 
1. What is the ethnolinguistic knowledge of the classroom teacher in the Indonesia elementary school?

2. How do class teachers implement ethnolinguistics in low-class and high-class learning in Indonesia Primary School?

3. What are the obstacles faced by class teachers in implementing ethnolinguistics in low-class and high-class learning in Indonesia Primary School?

\section{Method}

This study uses a combination approach (mix methods). According to Creswell (2009) "mixed methods research is an approach to inquiry that combines or associates both qualitative and quantitative forms it involves philosophichal assumptions, the use of qualitative and quantitative approaches, and the mixing of both approaches in a study". The research design used in this study is a sequential explanatory design. This study uses a mixed method because it has two types of data, namely the first data is quantitative data.

The sample in this study were 18 teachers from 3 elementary schools in Pemayung sub-district, Indonesia. The researcher chose all populations to be sampled because of the relatively small population. The sampling technique used in this study was nonprobability sampling. The sampling technique used is purposive sampling. Cohen (2005) "they build up samples that are satisfactory to their specific needs. As its name suggests, the sample has been chosen for a specific purpose ". Consideration or selection criteria for the sample used in this study are 1) Judging from the ethnolinguistic knowledge of teachers in elementary schools; 2) Low-grade teachers and high school Elementary class; 3) Class teachers who are in 3 Pemayung sub-district elementary schools.

Data collection techniques in this study used quantitative data collection techniques and qualitative data collection techniques. The quantitative data collection technique used was in the form of a questionnaire. Qualitative data collection techniques used are interviews and document analysis. This study uses a questionnaire that measures the extent to which ethnolinguistic science possessed by teachers to be applied in learning with a statement of 14 items. The interview technique used is structured interviews. Interviews were used to find out how the teacher in implementing ethnolinguistics in the classroom and to find out the obstacles faced by the teacher implementing ethnolinguistics. Documentation analysis is used to supplement teacher data on ways to implement ethnolinguistics in the classroom. The technique of testing the validity of the instrument on quantitative data is the questionnaire using the test of content validity, construction validity, and external validity. The instrument validity test technique on qualitative data obtained from interviews and document analysis was used to test the content validity and construct validity. Quantitative data analysis techniques used descriptive statistics. Presentation of data using tables and pie charts. Qualitative data analysis techniques using the analysis of the Miles and Huberman models.

\section{Result}

3.1 Ethnolinguistic Knowledge of elementary school teachers in Indonesia

Respondents in this study were 18 teachers. Of the 18 teachers sampled found the following results. Table 1 Ethnolinguistic Knowledge of Primary School Teachers in Indonesia

\begin{tabular}{|c|c|c|c|c|c|c|c|c|c|}
\hline \multicolumn{3}{|c|}{ Category } & \multirow{2}{*}{$\begin{array}{l}\text { Standard } \\
\text { Deviation }\end{array}$} & \multirow[t]{2}{*}{ Mean } & \multirow[t]{2}{*}{ Mode } & \multirow[t]{2}{*}{ Median } & \multirow[t]{2}{*}{ Min } & \multirow{2}{*}{ Max } & \multirow{2}{*}{$\%$} \\
\hline Range & $\begin{array}{l}\text { Ethnolinguistic } \\
\text { Knowledge }\end{array}$ & Tot & & & & & & & \\
\hline $\begin{array}{l}18- \\
24.5\end{array}$ & Not Good & 4 & & & & & & & $\begin{array}{l}22 . \\
22 \%\end{array}$ \\
\hline $\begin{array}{l}25- \\
31.5\end{array}$ & Less Good & 6 & 7.160 & 30.72 & $27^{\mathrm{a}}$ & 30.50 & 18 & 44 & $33.33 \%$ \\
\hline $\begin{array}{l}32- \\
38.5\end{array}$ & Good & 5 & & & & & & & $\begin{array}{l}27 . \\
78 \%\end{array}$ \\
\hline $\begin{array}{l}39 \\
45.5\end{array}$ & Very Good & 3 & & & & & & & $\begin{array}{l}16 . \\
67 \%\end{array}$ \\
\hline Total & & 18 & & & & & & & $100 \%$ \\
\hline
\end{tabular}




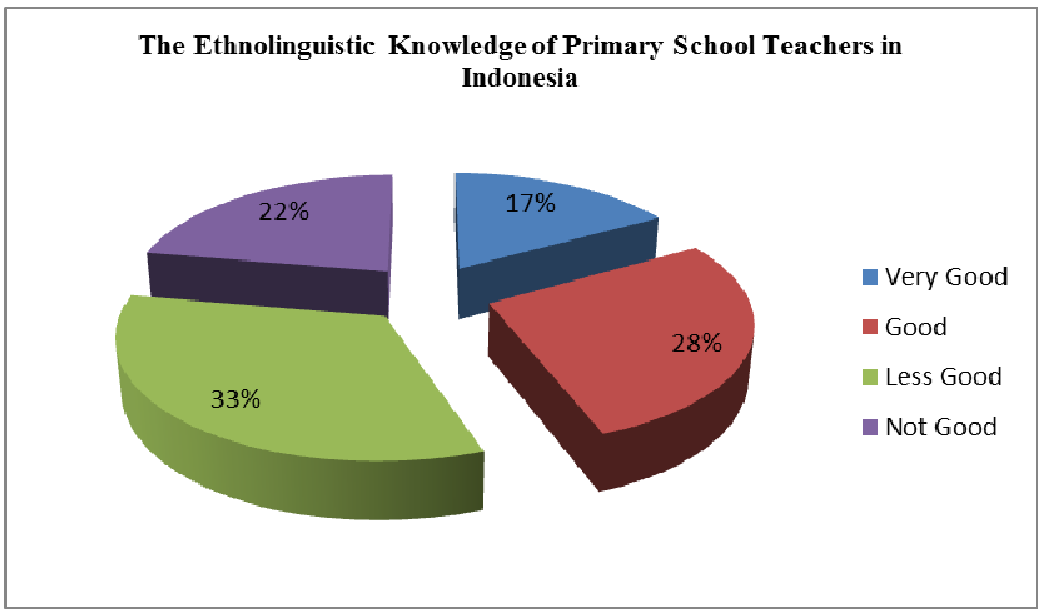

Figure 1. Diagram of Ethnolinguistic Knowledge of Primary School Teachers in Indonesia

Based on the picture in the graph above, the results obtained from questionnaire data as many as 18 respondents showed that for the category of ethnolinguistic knowledge very good as many as 3 out of 18 teachers with a percentage of $17 \%$, both $28 \%$ with a total of 5 out of 18 teachers, less than 6 of 18 teachers with a percentage of $33 \%$ and bad categories with $22 \%$ as many as 4 out of 18 teachers. This shows that elementary school teachers in Indonesia have ethnolinguistic knowledge in poor categories with an average of 30.72 and the percentage of poor categories is $33 \%$, which is 6 out of 18 teachers.

\subsection{Implementation of Ethnolinguistic Sciences in Teachers in Low and High-Class Learning in Indonesia Elementary School}

The results of interviews regarding the ways teachers use ethnolinguistics in daily learning can be explained as follows:

1. Using regional language as the language of instruction in learning by inserting regional languages during core learning activities, namely when giving explanations to students: "Especially in regional languages, I used to use regional languages as the language of instruction, because by using regional languages students were faster at understanding. After that, it will be taught in Indonesian. The teacher corrects the sounds of language intonation. Even though they come from the regions but students have good Indonesian language skills "(Teacher interview November $28^{\text {th }}, 2018$ ).

2. By way of inserting regional languages into spontaneous learning: "Spontaneously, for example mathematics determines angles. the regional language of Jambi is the same as 'bucu'. Spontaneously use local languages" (Teacher interview November $28^{\text {th }}, 2018$ ).

3. Integrating regional language into the content of learning carried out when giving examples of the use of vocabulary with regional languages: "For example a high class there is a term that the child does not know about learning material, then we give it in an example of a local language such as what language is the language what area does the child understand this local language and this is the default language. Generally, if the low-class children still use the language of the mother, so the language they bring is the language of their own home. But for this high class, there have been developments in terms of language "(Teacher interview, November $27^{\text {th }}$, 2018).

"For example, the local language is if ounces means 'mato'. So if I say actually 'mato' is Jambi language. Ounces are Indonesian. So 1 ounce means 100 grams. That's what I often teach children "(Teacher interview November $\left.28^{\text {th }}, 2018\right)$.

4. Linking one theme to another: "In general, the low class still uses regional language. But in my class, I optimize good and correct language. Yes, it's like seloko and pantun. For example, such as synonyms for the similarity of words with regional languages, only the pronunciation is different "(Teacher interview November $28^{\text {th }}, 2018$ ).

The results of the lesson plan document analysis on the ways teachers use ethnolinguistics in daily learning, there are 10 out of 18 teachers who complete the lesson plan documents. It was found that the implementation of learning with ethnolinguistics was not carried out because in the item statement about integrating ethnolinguistics in preliminary activities, core activities, concluding, and teacher assessments did not include activities regarding ethnolinguistic integration into the lesson plan. The use of ethnolinguistics has not been included by the teacher into the lesson plan.

3.3 Constraints Faced by Teachers in Implementing Ethnolinguistic Sciences

The results of interviews regarding the obstacles faced by teachers in implementing ethnolinguistics can be 
reported as follows. Teacher constraints in implementing ethnolinguistics can be viewed from several aspects, namely:

1. The environment of students who are immigrant communities: "The problem is that students in the class have different tribes. Because we live in the Jambi area, but because there are Javanese students, the ethnolinguistics is automatically different because at home they use the language of their parents while in the school there is a regional language used by the teacher" (Teacher interview November $28^{\text {th }}, 2018$ ).

2. There is a difference in ability or knowledge of each student: "Character of different students and abilities of children. Children in the class use Indonesian, but the method of explaining it must be mixed using local languages, but the application of the language used is Indonesian" (Teacher interview November $28^{\text {th }}, 2018$ ).

3. Lack of teacher's understanding of regional language vocabulary because there are teachers who come from migrant areas so that the teacher does not understand the knowledge of regional languages: "This constraint is just a vocabulary extension. But the obstacle hasn't been seen yet. Most mothers only tell the child about the Jambi languages, read the story. If the problem is the mother sees the dictionary. There is a regional language in dictionary" (Teacher interview November $27^{\text {th }}, 2018$ ). "The first is that the kits themselves are not from here. But there is a connection that we are also both Malay and Jambi, so we understand a little more, however, the specificity of the dialect or how many of these local residents we do not understand" (Teacher interview November $\left.28^{\text {th }}, 2018\right)$.

4. Limited use of learning media and material development in implementing ethnolinguistics: "It is not possible for us to learn directly. The obstacle is in the area of the regional language. Constrained because the media is not there. So it affects the success of students" (Teacher interview November $28^{\text {th }}, 2018$ ).

5. Instructions for using ethnolinguistics that has been included in learning and lesson plans have not been submitted by the education office or discussed in the KKG (teacher's work group) forum: "Because all this time, from superiors, it has never been said that local wisdom should be conveyed here, never. Nothing at the KKG (teacher's work group) forum was explained about that. If for example there were orders from superiors, of course, the education office in the KKG (teacher's work group) forum would definitely be discussed" (Teacher interview November $28^{\text {th }}, 2018$ ).

\section{Discussion and Recommendation}

Ethnolinguistics literally comes from the ethnos word which means tribe and linguistics which means linguistics. Ethnolinguistics is a combination of ethnology and linguistics. Ethnolinguistics in the learning perspective is the knowledge that teachers have about regional languages that are related or included in learning. This ethnolinguistic knowledge is important for a teacher because ethnolinguistic knowledge students can easily understand learning. Based on the findings in the field obtained from the questionnaire results, ethnolinguistic knowledge of elementary school teachers in Indonesia showed that elementary school teachers in Indonesia had ethnolinguistic knowledge in poor categories with an average of 30.72 and a percentage of poor categories $33 \%$, 6 of 18 people teacher. Based on these results it can be concluded that ethnolinguistic knowledge of elementary school teachers in Indonesia falls into the less good category.

\subsection{The Strategy or Ways of Teachers in Implementing Ethnolinguistic Sciences}

The way the teacher implements the first ethnolinguistics is to make regional languages an introduction to learning by inserting regional languages during core learning activities, namely when giving explanations to students. As stipulated in Law Number 20 of 2003 concerning Article 33 of the National Education System concerning the language of instruction it is stated that the language of instruction in national education is Indonesian (paragraph 1) however, regional languages can be used as the language of instruction in the early stages of education if needed submission of certain knowledge and / or skills (paragraph 2).

Students will feel a more intimate and pleasant atmosphere because they assume that teachers better understand the world of those who still use mother tongue or regional languages in interacting with others (Sari, 2015). Situationally, the use of the regional language needs to be considered because some introductory Indonesian language used in learning causes students do not understand in learning a week, the regional language needs to be used to approach the learning material. Teachers in the teaching and learning process are allowed to use regional languages to help understand students who are still not fluent in Indonesian (Sari, 2015). Furthermore, the way the teacher inserts the regional language into learning can be done by inserting the regional language into learning spontaneously. The teacher spontaneously inserts the regional language vocabulary in learning in order to link learning directly to the context. Regional language learning which is taught spontaneously is carried out with the use of Indonesian language which is inserted in the regional language. This method has never been used before. This is a new discovery because no research has been found on this. Participants in this study have initiatives that are in accordance with the learning sciences to the elementary school.

This finding has also not been found in a journal in Indonesia. However, this is relevant to the theory of 
How People Learn according to (Bransford, et. Al, 2000) Students come to the classroom with preconceptions about how the world works. If their initial understanding is not engaged, they may fail to grasp the new concepts and information that are taught, or they may learn for the purposes of examining their preconceptions outside the classroom. Based on constructivist views, students will learn well if they can bring learning into the context of what they are learning into the application of daily real life and benefit themselves (Rusman, 2015) ".

The way to integrate regional language into the content of learning is then carried out when giving examples of vocabulary usage in regional languages. An integrated model, the implementation of local wisdom is inherent and integrated in curricular programs, existing curricula and / or existing subjects, even the learning process (Sudarmin, 2014). As the research findings explained by the teacher, this example of ethnolinguistics can be implemented in the content of mathematics learning. For example for material mass units in mathematics learning content, there is a regional language with the term mato to express ounces. If students are taught with the term ounce, students are confused. Sari (2015) states that "One of the factors causing students having difficulty communicating is that students do not understand the contents of the teacher's speech because of the lack of vocabulary in students. Students will better understand the contents of the talk of the teacher who is not too formal to use Indonesian, but uses Indonesian and the local language".

The teacher's method or strategy in implementing ethnolinguistics in the next class is by relating themes to themes. Based on the research findings, it is known that the teacher's way of implementing ethnolinguistics in the classroom is by linking one theme with another theme such as linking pantun with seloko, synonyms associated with the words with local language vocabulary, writing stories related to writing stories of Jambi people's struggle. This finding is supported by previous research by Panca Junita Sari (2015) with the title Sociolinguistics as the Basic Foundation for Education in Primary Schools. The results of this study indicate that in the 2013 curriculum on the content of learning Indonesian contains basic competencies "Writing simple narrative texts activities and playing in the environment with the help of teachers or friends in oral and written Indonesian can be filled with the vocabulary of regional languages to help to understand". This shows that teachers in the delivery of material are allowed to use or fill in the vocabulary of regional languages to help to understand in writing simple narrative texts. In this relevant study, there are few differences, namely in this study examines the way teachers in implementing ethnolinguistics in the classroom, especially in the use of regional languages, which can be done by linking a learning topic. However, in relevant research studies sociolinguistics in terms of the analysis of Basic Competency in Curriculum 2013 regarding bilingual used in learning as the basic foundation in education in elementary school.

\subsection{Teacher Constraints in Implementing Ethnolinguistic Sciences}

Teacher constraints in implementing ethnolinguistics in learning are due to the environment of students who are immigrant communities. Rosita, et al (2006) "The background of children's culture, especially regional language, must be a force that can influence him in interacting with the teacher in compiling knowledge in the mind of the child". Many students come from Java, so the language used is the Javanese language they get from the family. Therefore, mother tongue is closely related to regional languages where an individual is born, large and lives (Ibda, 2017). In students who have a family background rather than the environment, they must learn a lot in order to be able to adjust their new environment with different regional languages so that they can continue to exist in the new environment (Rosita et al., 2006).

The obstacle experienced by the next teacher is the difference in ability or knowledge of each student. Sari (2015) One of the factors that make it difficult for students to communicate is that students do not understand the contents of the teacher's speech because of the lack of vocabulary in students. Students will better understand the contents of the teacher's conversation that is not too formal to use Indonesian but uses Indonesian and the local language. Based on the research findings, the constraints faced by teachers in implementing ethnolinguistics are the level of understanding or material absorption by different students. Relevant research in one context regarding the constraints studied from the different levels of understanding of students has not been found because new findings can be categorized.

The next obstacle is the lack of understanding of teachers in regional language vocabulary because there are teachers who come from migrant areas so that the teacher does not understand the knowledge of the local language. This will affect the students themselves because students who come from the local area and are accustomed to using their mother tongue in communication are required to master the Indonesian language. The teacher must also learn regional languages to help understand students and facilitate the teaching and learning process (Sari, 2015). Relevant research in one context with this research, which is examined from the obstacles faced by teachers in implementing ethnolinguistic knowledge has not been found.

The constraints experienced by teachers in terms of the use of learning media in implementing ethnolinguistics have not been implemented. Media is one of the supporting factors for the success of learning, especially in implementing this ethnolinguistic science. Judging from the material, based on the findings, the teacher also experienced obstacles to the material because not all material can be integrated with this 
ethnolinguistic knowledge. The limitations of the service to facilitate regional language material and indicators regarding it were not given serious reinforcement from the service. Sudaryat (2004) "teachers in the area or at school can develop, combine, or adapt materials presented with local conditions and needs in syllabus and learning plans". Sudarmin (2014) An integrated (integrative) model requires high readiness and ability from schools, principals and subject teachers.

In addition to the constraints that have been described above, it was found that the obstacles in implementing ethnolinguistic science were reviewed by the education office or discussed in the KKG (teacher's work group) forum. Ethnolinguistic content (regional language) is implicitly inserted by the teacher into learning. In particular, the teacher has not focused on ethnolinguistics contained in the lesson plan. The shortage of teachers in exploring ethnolinguistics into learning is due to the teacher's weak ability in the field of ethnology. According to Sudarmin (2014) "Education that is approached or based on local wisdom will certainly succeed if the teacher understands the insights of local wisdom itself. Teachers who do not understand local wisdom tend to be less sensitive to local cultural diversity. These conditions prove that in pedagogical competencies teachers experience problems. Therefore, important ethnolinguistic knowledge is possessed by a teacher. To support the success in implementing learning in elementary school.

\section{Conclusion}

From the results of the research, the following things can be concluded the ethnolinguistic knowledge of elementary school teachers in Indonesia in less good category. Implementation of ethnolinguistic knowledge of elementary school teachers in Pemayung sub-district is carried out by: a. Using regional language as the language of instruction in learning is carried out by inserting regional languages during core learning activities, namely when giving explanations to students; b. By way of inserting regional languages into learning spontaneously; c. Integrating regional languages into the content of learning carried out when giving examples of the use of vocabulary with regional languages; The use of ICT in implementing science has not been optimally implemented; d. Linking one theme to another. Constraints faced by teachers in implementing ethnolinguistics in low-class and high-class learning, namely: $a$. The environment of students who are immigrant communities; $b$. The difference in ability or knowledge of each student; c. Lack of teacher understanding in regional language vocabulary because there are teachers who come from migrant areas so that the teacher lacks understanding of regional language knowledge; d.The limited use of learning media and material development in implementing ethnolinguistics has not been implemented; e. Instructions for using ethnolinguistics that are included in learning and lesson plans have not been delivered by the education office or discussed in the KKG (teacher's work group) forum.

This study has produced preliminary findings, it is expected that further research from this study is expected. Particularly deepening the instructions for using ethnolinguistics into learning in the form of modules that can be used as guidelines in the implementation of ethnolinguistics.

\section{References}

Adilah, G. 2013. Enhacing Local Wisdom Through Local Content Of Elementary School In Java, Indonesia. Kuala Lumpur: Proceding of the Global Summit on Education 2013.E-ISBN 978-967-11768-0-1.

Anggraini, Purwati dan Kusniarti, Tuti. 2015. The Insertion of Local Wisdom into Instructional Materials of Bahasa Indonesia for 10th Grade Students in Senior High School. Journal of Education and Practice. University of Muhammadiyah Malang. ISSN 2222-1735. Vol.6(33), 89-92.

Beauchamp, George, A . 2009. Curriculum theory: Meaning, development, and use. Wilmette, Illions: KAGG Press

Berkowitz, M.W and Hoppe, M,A. 2009. Character education and gifted children. High Ability Studies (online). Vol. 20(2). ISSN 1359-8139 DOI: hhtp://dx.doi.org/10.1080/13598130903358493

Bransford, John, D., Brown, Ann, L., and Cocking, Rodney, R.: 2000. How People Learn: Brain, Mind, Experience, and School: Expanded Edition. Washington, D. C: National Academy Press. ISBN 978-0-30907036-2. DOI 10.17226/9853

Cohen, Louis, Manion, Lawrence, \& Morrison, Keith. 2005. Research Methods in Education- 5 th ed. London and New York: Taylor and Francis e-Library. ISBN: 0-203- 22434- 5.

Creswell, J.W. 2009. Research Design Third Edition. University Of Nebraska Lincoln: SAGE Publication

Ibda, H. 2017. Urgensi Pemertahanan Bahasa Ibu di Sekolah Dasar. Jurnal Shahih: LP2M IAIN Surakarta. Vol. 2( 2), 194-206. ISSN: 2527-8118

Republik Indonesia. 2003. Undang-Undang Republik Indonesia Nomor 20 tentang Sistem Pedidikan Nasional. Jakarta: Departemen Pendidikan Nasional

Riley, Philip. 2007. Language, Culture and Identity.UK: Athenaeum Press L.td. ISBN: 978- 08264-86288

Rosita, A dan Aprila, F. 2006. Pentingnya Mata Pelajaran Bahasa Daerah dalam Kurikulum Sekolah Dasar dalam Eksistensi Bangsa. Pengembangan Pendidikan, Vol 3(1), 35-43. 
Rusman, 2015. Pembelajaran Tematik Terpadu. Jakarta : PT Raja Grafindo

Sari, P, J. 2015. Sosiolinguistik Sebagai Landasan Dasar Pendidikan di Sekolah Dasar. Bengkulu. Prosiding Seminar Nasionak Bulan Bahasa: UNIB

Sudarmin. 2014. Pendidikan Karakter, Etnosains dan Kearifan Lokal. Semarang: Unnes

Sudaryat, Y. 2008. Pengembangan Pembelajaran Bahasa Daerah. Modul (PLPG) Mata Pelajaran Muatan Lokal Bahasa Daerah UPI. 